\title{
Make and match method supported by picture media to improve students' learning activity
}

\author{
R.T. Setyawati, W. Sukartiningsih \&W. T. Subroto \\ Faculty of Education: Department of Elementary school of teacher education \\ Universitas Negeri Surabaya \\ Surabaya, Indonesia \\ wahyusukartiningsih@unesa.ac.id
}

\begin{abstract}
This research aims to describe the increase of students' activity through the application of make and match method supported by picture media. This research is a Classroom Action Research with descriptive quantitative approach. Observation and documentation were used in collecting the data. The data obtained were then analyzed and described in descriptive quantitative form. The research was conducted in 2 cycles. After applying make and match method supported by the picture media, the researcher got the result according to the success indicator. The observation result of students' learning activity increased from $76,3 \%$ in cycle $I$ to $92 \%$ in cycle II which belonged to very good category. It can be concluded that applying make and match method supported by picture media can improve students' learning activity.
\end{abstract}

Keywords-make and match method; learning activuty; classroom action research

\section{INTRODUCTION}

In teaching and learning process, students should be more active in order to work well with teachers' plan. According to [1], one characteristic of the 2013 Curriculum is the balance of attitudes, knowledge and skills to develop students ' soft and hard skills. In accordance with Piaget's cognitive development theory, elementary school students are at a concrete operational stage. Children's ability is still limited to the concrete things, then their process of thinking will occur in the direct activities. Students will have difficulty in solving problems by simply relying on their brain power without trying to do activities (direct experience). The formulation of the research problem is how the learning activities undertaken by students in the implementation of learning make and match method supported by the picture media.

According to [2], "The cooperative learning approach is easily combined with many other approaches to teaching and learning". Slavin's cooperative learning study suggests that cooperative learning enhances interaction among students by providing them with fun activities together and establishing their basis for sharing commonalities (group membership), as well as engaging them to work together to achieve goals together [3, 4]. In fact, fun activities can improve social sense which is also explained in Vygotsky's learning theory that the learning results should be in accordance with the leaning objectives [5].

"Reference by [6] revealed that make and match model is a model of learning that can be applied to all subjects and levels. In this model, students looking for the pair while studying a concept in a pleasant atmosphere. Make and match learning model is a part of cooperative learning that can be used as an effective alternative in achieving learning objectives.

Cooperative learning model is based on the philosophy of homo hominy socius which emphasizes that man is a social being [7]. The procedure of make and match model starts from preparing several cards containing appropriate topic then each student will be given a kart and guided to do matching game [6]. Other students can join to hold the corresponding card. According to [8], students ' learning activities are essential elements for the success of the learning process. Learning activities are also defined as the various activities that are given to students in teaching and learning situations. This learning activity is designed to enable students to obtain the specified content, so that the various objectives set can be achieved. The activities referred here are not only physical activities but also mental activity. In the learning activities, both activities are interconnected [9].

The concept of picture media, as stated by [10] that this type of media is the most commonly used media, which has been broadly discussed by many parties. The use of picture media has many advantages both in use and procurement. The same study on the concept of picture media explained that the picture media are the most common graphics media used in the learning process. Picture media are widely used due to several reasons, $[10,11]$ explained that employing picture media as learning method can improve students' learning outcomes since the students are eager to understand what they see instead of fantasizing it.

\section{METHOD}

This research is a Classroom Action Research (CAR) which is defined as an attempt to examine learning activities of a group of learners by providing a treatment (treatment) that is deliberately raised in order to improve learning quality [12]. 
Classroom Action Research Model is divided into four stages covering planning, execution, observation, and reflection which employed descriptive quantitative analysis. The data were obtained by using observation and documentation technique then analysed using simple quantitative formulas. The analysis result were described or elaborated in descriptive quantitative form. The data of student learning activity during learning activity were analysed using percentage calculation. The calculation is as follows:

$$
P=\frac{f}{N} \times 100 \%
$$

Information

$P=$ the result of student activity in the form of percent

$\mathrm{f}=$ the score of each aspect activity

$N=$ analyst amount multiplied the maximum score

(Djamarah, 2000)

TABEL 2.1 Criteria Percentage of Individual Students' Learning Activity

\begin{tabular}{|c|c|c|}
\hline $\begin{array}{c}\text { Achieving } \\
\text { Learning } \\
\text { Objectives }\end{array}$ & Qualification & $\begin{array}{c}\text { Success Level of } \\
\text { Learning }\end{array}$ \\
\hline $85 \%-100 \%$ & Very Good & Success \\
\hline $65 \%-84 \%$ & Good & Success \\
\hline $55 \%-64 \%$ & Enough & Not success \\
\hline $0 \%-54 \%$ & Less & Not success \\
\hline \multicolumn{2}{|c}{ (Aqib, 2009) }
\end{tabular}

Students' classical learning activities Percentage of succes $=\frac{\text { amount of active student }}{\text { amount student in the classroom }} \times 100 \%$

\section{RESULT AND DISCUSSION}

\section{A. Description of Research Results in Cycle I}

\section{Planning cycle 1}

Students did not understand or master the material of Pancasila symbol because during this time the students were still using rote memorization of a concept. In addition, the learning done was boring because it was dominated by teachers. At the planning stage, the action conducted by the researchers are in the form of making learning tools, making learning media, organizing instruments and creating validation sheets and setting indicators of success in research.

\section{Implementation of Action Cycle and Observation I}

Observation data of students' learning activity in cycle I obtained then presented in the form of bar chart in Diagram 1.
Diagram 1. Observation Results of Students' Learning Activity in Cycle I

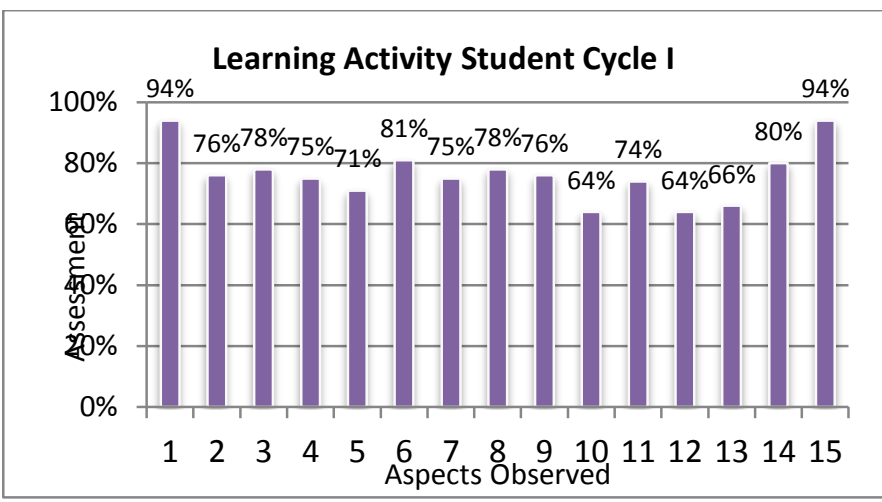

Aspects observed

1. Praying before lesson started

2. Listening to the teacher's explanation

3. Singing Garuda Pancasila song

4. Observing the symbol of Burung Garuda (Eagle)

5. Frequently asked questions about the symbol of Pancasila

6. Mentioning the points of Pancasila

7. Forming groups with teacher's guidance

8. Holding a question/answer card

9. Reading the answer cards/questions held

10. Finding the pairs of cards held before the given time limit

11. Pairing the appropriate answer card correctly

12. Delivering the results of the answer/problem card pairs

13. Summing up the material learned

14. Completing the question instrument

15. Praying after the lesson

From the observation results of learning activities in cycle I, learning activities undertaken by students at the time of learning by using the picture media turned out good. It can be seen from the percentage of students' learning activity as a whole reached good category with the average value of $76.3 \%$.

\section{Reflection of Cycle I}

Observation results of successful students' learning activity included praying before learning, listening to the teacher's explanation, singing song, observing symbol, questioning, forming group, holding question/answer card, reading card of question/answer held, finding pairs of cards held before time limit set, pairing cards with the answer correctly, and delivering the results of the card pairs, as well as summarizing the material then praying after the lesson. However, there were 
some obstacles that made students' learning activity had not reached the expected completeness of $80 \%$. According to the results of reflection at the end of cycle I, it was necessary to conduct cycle II to improve the learning process of Pancasila symbol with make and match method. This was done to fix the weakness occurred in cycle I.

\section{B. Description of Research Results in Cycle I}

\section{Early reflection}

The problems faced in the first cycle would be addressed in the second cycle. Based on the observations made by the students' learning activities at the time of learning there are still some aspects that need to be improved, i.e. pairing questions/answers cards precisely before the time is up and concluding learning materials.

\section{Planning cycle II}

As in cycle I, in cycle II the teacher prepared several things to be implemented in the learning process. At this stage, there were several things that must be done to make learning devices used in the learning process with symbols of Pancasila as learning material. However, in cycle II, the researchers made some adjustments to the learning devices to improve the existing cycle in cycle I. The suggestion mentioned would be realized in the learning devices used in cycle II.

\section{Implementation of Action and Cycle Observation II}

The observation results of students' learning activity in the Cycle II were presented in Diagram 3.2 as follows.

Diagram 2. Observation Results of Students' Learning Activities in Cycle II

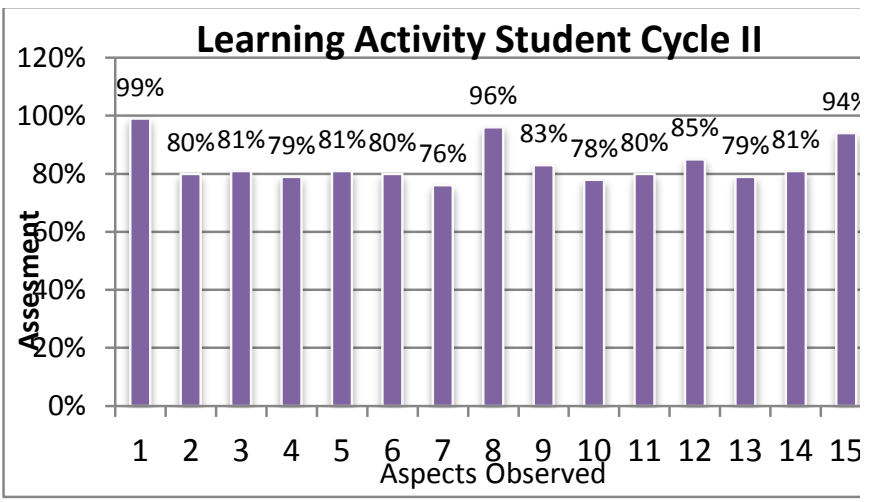

Aspects observe

1. Praying before lesson started

2. Listening to the teacher's explanation

3. Singing Garuda Pancasila song

4. Observing the symbol of Burung Garuda (Eagle)

5. Frequently asked questions about the symbol of Pancasila

6. Mentioning the points of Pancasila

7. Forming groups with teacher's guidance
8. Holding a question/answer card

9. Reading the answer cards/questions held

10. Finding the pairs of cards held before the given time limit

11. Pairing the appropriate answer card correctly

12. Delivering the results of the answer/problem card pairs

13. Summing up the material learned

14. Completing the question instrument

15. Praying after the lesson

From the observation results of the learning activities cycle II, the activities undertaken by students at the time of learning using make and match method supported by the picture media turned out very good. This was seen from the percentage of student activity as a whole had reached very good category with an average of $92 \%$.

\section{Reflection cycle II}

Based on the observation results in cycle II, the researchers did a reflection to see the weaknesses occurred to be improved in the next cycle. Students' activity increased by $15.7 \%$ after the improvement done in cycle II. The percentage of student activity in the first cycle was $76.3 \%$ and increased in cycle II to $92 \%$ with very good category. The comparison of learning activity value in cycle I and cycle II can be seen in Diagram 3.3.

Diagram 3. The percentage of students' learning activity in cycle I and cycle II

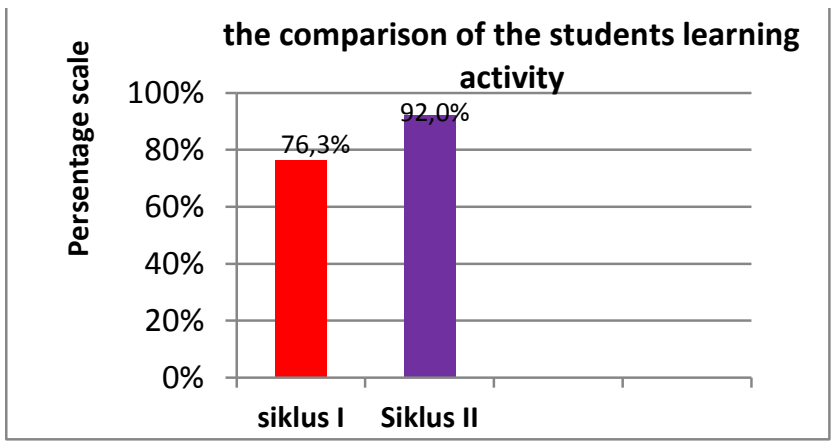

In diagram 3.3 , it can be seen that students' learning activities by applying make and match method supported by the picture media increased by $15.7 \%$ from $76.3 \%$ (good) in the cycle I to $92 \%$ (very good).

In this research, the observation done in 2 cycles. According to [13], students' learning activities are essential elements for the success of the learning process. Learning by implementing make and match method improved students' activity. From the observation results of cycle I, the activities undertaken by students at the time of learning by using picture media fell into good category. It was seen from the percentage of students' activity as a whole reaching average value of $76.3 \%$. 
Hall's theory put forward by Granville Stanley Hall in his study of child psychology proposed that the developmental stage of mental behavior and mental function, children aged 0 12 years love game. Specifically, the psychological development of children aged 8-12 years is in the stage of getting interested in playing in groups. Based on the theory, the learning using make and match method is suitable for elementary school children since it is packed in the form of interesting game and can increase students' activity. After the reflection, the researchers conducted a continuation cycle to achieved a very good status. This was seen from the percentage of student activity as a whole which fell into very good category with an average of $92 \%$.

Students' learning activities using make a match is also in accordance with the study put forward by $[14,15]$. According to [15], this method has advantages include: increasing students' learning activities both cognitively and physically, this method is more fun because in the form of games, improving students' understanding of the material learned and improving students' learning motivation, developing students' courage to do presentation, and training students' discipline to appreciate the time to learn.

\section{CONCLUSION}

Based on the results, the application of make and match method supported by picture media can increase students' learning activity. After applying make and match method, students' learning activity increased by $15.7 \%$ from Cycle I to $76.3 \%$ and $92 \%$ in cycle II.

\section{REFERENCES}

[1] F. Fauzan, "Analysing The Essence of Fiqh Subjects In Curriculum 2013," AHKAM: Jurnal Ilmu Syariah, vol. 17, 2017.

[2] M. S. Saltymakov and E. O. Frantcuzskaia, "Cooperative Learning Approach to Delivering Professional Modules to Bachelor and Master Students: TPU Experience," Procedia-Social and Behavioral Sciences, vol. 215, pp. 90-97, 2015.

[3] J. J. Juelis, Parallels between cooperative play and multicultural education: University of Washington, 2009.

[4] R. Slavin and D. Smith, "The relationship between sample sizes and effect sizes in systematic reviews in education," Educational Evaluation and Policy Analysis, vol. 31, pp. 500-506, 2009.

[5] L. S. Vygotsky, The collected works of LS Vygotsky: Problems of the theory and history of psychology vol. 3: Springer Science \& Business Media, 1997.

[6] B. R. Joyce, M. Weil, and E. Calhoun, Models of teaching vol. 499: JSTOR, 1986.

[7] J. R. Savery and T. M. Duffy, "Problem based learning: An instructional model and its constructivist framework," Educational technology, vol. 35, pp. 31-38, 1995.

[8] D. W. Johnson and R. T. Johnson, Cooperative learning: Wiley Online Library, 2008.

[9] M. Salvatori, "Reading and writing a text: Correlations between reading and writing patterns," College English, vol. 45, pp. 657-666, 1983.
[10] L. Masterman, "A rational for media education," Media Literacy in the Information Age. New Brunswick (USA) and London (UK): Transaction Publishers, pp. 15-68, 1997.

[11] J. W. Tankard, "The empirical approach to the study of media framing," Framing public life: Perspectives on media and our understanding of the social world, pp. 95-106, 2001.

[12] J. W. Stigler and J. Hiebert, The teaching gap: Best ideas from the world's teachers for improving education in the classroom: Simon and Schuster, 2009.

[13] M. S. Segers, "Assessment in a problem-based economics curriculum," in Alternatives in assessment of achievements, learning processes and prior knowledge, ed: Springer, 1996, pp. 201-224.

[14] K. Wastawan, C. Sutarsyah, and S. Sudirman, "Increasing Students Reading Comprehension Through Make A Match Type Of Cooperative Learning," U-JET, vol. 3, 2014.

[15] R. Garris, R. Ahlers, and J. E. Driskell, "Games, motivation, and learning: A research and practice model," Simulation \& gaming, vol. 33, pp. 441-467, 2002. 